\title{
Structure and properties of ceramic brick colored by manganese-containing wastes
}

\author{
Andrey Stolboushkin ${ }^{1}$, Danil Akst ${ }^{1, *}$, Oksana Fomina ${ }^{1}$, and Aleksandr Ivanov ${ }^{1}$ \\ ${ }^{1}$ Siberian State Industrial University, 654007 Novokuznetsk, Russia
}

\begin{abstract}
The given paper investigates the influence of manganesecontaining wastes on bulk coloring and physical and mechanical properties of wall ceramic materials with matrix structure. Conventional research methods to study physical and mechanical properties of ceramic specimens were used in the present study. The structure and phase state of decorative ceramic materials were investigated by means of physical-chemical analysis. Authors suggested the model to form coloring layer in ceramic matrix composites based on argillaceous raw materials and coloring pigment. Macrostructure was studied on ceramic samples manufactured according to the developed method from clay loam of moderate plasticity and wastes of manganese mining. The paper provides results of pilot testing on production of colored ceramic brick. It was found that incorporation of coloring component does not decrease strength properties of ceramic matrix materials. Authors defined the palette and color code for decorative ceramic specimens manufactured with different content of coloring component of manganese mining wastes according to RGB color codes chart.
\end{abstract}

\section{Introduction}

Rational selection of building materials plays an important role in construction. Building materials quality primarily defines strength, reliability and durability. Along with that, decorative properties are also of great importance as they define the outside look of a building.

Facing and decorative ceramic brick belongs to such materials. Various techniques have been used for its manufacture so far [1-5]. Currently, bulk coloring of ceramics has been considered to be one of the most popular techniques among them. Coloring of wall materials is conducted by incorporation of light-burning clays, various mineral additives or coloring metal oxides into furnace charge $[6,7]$. Use of pure oxides for structural coloring of brick is retained due to their high cost, thus leading to appreciation of ceramic manufacture and reduced competitiveness of products on the market.

Efficient use of industrial wastes for obtaining ceramic brick with the required operational and decorative properties is one of the promising directions of wall ceramic materials development. Replacement of expensive coloring agents with industrial wastes containing coloring metal oxides [8] will enable to reduce expenses for brick manufacture

\footnotetext{
*Corresponding author: daniel_axt@mail.ru
} 
and enhance environmental situation in industrial areas $[9,10]$.

Analysis of modern production of colored brick using high-performance color modifiers [11-16] shows that bulk coloring of wall ceramic materials with oxide pigments generally causes a number of problems. One of the main problems is disruption of sintering process of argillaceous minerals while burning which leads to degradation of physical and mechanical properties of ceramics $[17,18]$.

The present paper is focused on application of manganese-containing wastes for structural coloring of ceramics and development of the way to form coloring shells around the clay granules. Selective structural concentration of wastes in clay brick by their minimum content will provide high coloring effect and decrease of their negative effect while sintering of ceramic products.

The given work is aimed at studying the influence of manganese-containing wastes on bulk coloring and physical-mechanical properties of ceramic brick with matrix structure.

\section{Materials and methods}

\subsection{Description of raw materials}

Argillaceous raw material used in the given study was clay loam collected from Berdsk deposit (Novosibirsk Region) peculiar for Siberian Region. Clay loam properties were: semi-acid, moderate-plasticity, low-melting, containing coarse-grain particles $(>0.01 \mathrm{~mm})$ less than 3\%. Tetravalent manganese oxide is one of the popular pigments used for ceramics bulk coloring. The wastes of manganese mining (WMM) of Selezen deposit (Kemerovo Region) were used as a coloring additive. Content of $\mathrm{MnO}_{2}$ in wastes comprised more than $25 \%$. Chemical and grain size composition of raw materials are given in Table 1 and Table 2 correspondingly.

Table 1. Chemical composition of raw materials.

\begin{tabular}{|l|c|c|c|c|c|c|c|c|c|c|c|c|}
\hline \multirow{2}{*}{ Raw material } & \multicolumn{7}{|c|}{ Mass content of components, \% (per pure dry substance) } \\
\cline { 2 - 12 } & $\mathrm{SiO}_{2}$ & $\mathrm{Al}_{2} \mathrm{O}_{3}$ & $\mathrm{FeO}$ & $\mathrm{Fe}_{2} \mathrm{O}_{3}$ & $\mathrm{CaO}$ & $\mathrm{MgO}$ & $\mathrm{TiO}_{2}$ & $\mathrm{MnO}$ & $\mathrm{R}_{2} \mathrm{O}$ & $\mathrm{P}_{2} \mathrm{O}_{5}$ & $\mathrm{SO}_{3}$ & $\begin{array}{c}\text { \% of other } \\
\text { impurities }\end{array}$ \\
\hline \hline $\begin{array}{l}\text { Berdsk clay } \\
\text { loam }\end{array}$ & 65.74 & 14.71 & 5.71 & 5.23 & 1.79 & 0.95 & 0.17 & 3.48 & - & 0.01 & 2.21 \\
\hline $\begin{array}{l}\text { Wastes of } \\
\text { manganese } \\
\text { mining }\end{array}$ & 32.39 & 12.18 & 12.81 & 2.41 & - & 25.17 & 0.49 & 0.16 & - & 13.55 \\
\hline
\end{tabular}

Table 2. Grain size composition of raw materials after blending.

\begin{tabular}{|l|c|c|c|c|c|}
\hline \multirow{2}{*}{ Raw material } & \multicolumn{5}{|c|}{ Fraction content, \%, particles size, $\mathrm{mm}$} \\
\cline { 2 - 6 } & $>0.06$ & $0.06-0.01$ & $0.01-0.005$ & $0.005-0.001$ & $<0.001$ \\
\hline \hline Berdsk clay loam & - & 2.6 & 65.05 & 4.18 & 28.17 \\
\hline $\begin{array}{l}\text { Wastes of manganese } \\
\text { mining }\end{array}$ & 41.71 & 36.71 & 7.5 & 12.73 & 1.35 \\
\hline
\end{tabular}

\subsection{Research methods}

The study of basic physical and mechanical properties of decorative ceramic materials with manganese-containing component was conducted on the laboratory cylinder specimens and factory-supplied bricks of dry compaction. Strength of bricks was defined according to the Russian National Standard GOST 8462-85 "Wall materials. Methods to define ultimate 
compressive and bending strength". Water adsorption and frost resistance were established in accordance with the Russian National Standard GOST 7025-91 "Bricks and ceramic and silicate stones. Methods to define water adsorption, density and frost resistance control".

The structure of ceramic samples was examined using the optical microscope Olympus GX-51 with polarizing accessory (Japan) and scanning electron microscope JSM-6460LV (JEOL, Japan).

X-ray investigation was performed with the help of diffractometer XRD-6000 (Shimadzu, Japan). The powders obtained from each of the layers were studied within the range of scanning $2 \theta$ from $4^{\circ}$ to $80^{\circ}$ at room temperature using FeK $\alpha$ radiation (Wavelength $1.936040 \AA$ ). Diffractometer settings were $40 \mathrm{kV}, 30 \mathrm{~mA}$, continuous scan, $2 \theta$ step width $0.02^{\circ}$ and speed $2 \mathrm{deg} / \mathrm{min}$.

\section{Experimental}

\subsection{Investigation of decorative ceramic specimens}

Previous works of authors were devoted to studying the influence of manganese ore production waste (WMM) on coloring of ceramic specimens produced from argillaceous raw materials [19]. The specimens were prepared in accordance with the developed methodology providing formation of matrix structure [19]. For that purpose fine-cut clay loam was aggregated in turbo-paddle type mixing grainer at simultaneous moisturization up to $11-13 \%$. Angular spin velocity of paddled blender of grainer was $15-20 \mathrm{~s}^{-1}$. Clay loam was granulated for 2-3 minutes until the granules with predominant size of 1-3 mm were formed. The final granulation stage included incorporation of additive from fine-grained WMM in order to form coloring layer along the granules surface. The actual moisture of granulated material "powdered with WMM" was 10-12\%.

Cylinder specimens were compacted from granulated batch under the pressure of 15 $17 \mathrm{MPa}$. Burning with isothermal curing for one hour was conducted at the temperature of $1000^{\circ} \mathrm{C}$.

Physical and mechanical properties of reference samples (without additive) and colored ones (with addition of $10 \mathrm{wt} . \%$ WMM) are given in Table 3.

Table 3. Physical and mechanical properties of ceramic samples.

\begin{tabular}{|c|c|c|c|c|c|c|}
\hline Sample & $\begin{array}{c}\text { Air } \\
\text { shrinkage, } \\
\%\end{array}$ & $\begin{array}{c}\text { Fire } \\
\text { srinkage, } \\
\%\end{array}$ & $\begin{array}{c}\text { Average } \\
\text { density, } \\
\mathrm{kg} / \mathrm{m}^{3}\end{array}$ & $\begin{array}{c}\text { Compressive } \\
\text { strength, } \\
\mathrm{MPa}\end{array}$ & $\begin{array}{c}\text { Water } \\
\text { adsorption, } \\
\%\end{array}$ & $\begin{array}{c}\text { Strength-density } \\
\text { ratio }\end{array}$ \\
\hline \hline reference & 1.6 & 1.4 & 1895 & 33.9 & 12.8 & 17.9 \\
\hline colored & 1.0 & 0.9 & 1962 & 38.6 & 12.5 & 19.7 \\
\hline
\end{tabular}

In order to conduct objective assessment of bulk coloring of ceramic specimens color codes were defined in accordance with RGB color code chart [20] and the resulting hexcode of color in hexadecimal number system formed by means of addition of basic color levels in the format \#RRGGBB [21]. The results are given in Table 4.

Table 4. Color palette and color codes of ceramic specimens.

\begin{tabular}{|c|c|c|c|c|c|}
\hline \multirow{2}{*}{ Specimen } & \multirow{2}{*}{ Adapted specimen color } & \multicolumn{3}{|c|}{ Color code according to RGB } & \multirow{2}{*}{$\begin{array}{c}\text { Color hex- } \\
\text { code }\end{array}$} \\
\cline { 3 - 5 } & & $\mathrm{R}$ & $\mathrm{G}$ & $\mathrm{B}$ & \# \\
\hline \hline Reference & & 179 & 89 & 37 & \#B35925 \\
\hline
\end{tabular}




\begin{tabular}{|c|c|c|c|c|c|}
\hline Colored & & 56 & 42 & 29 & $\# 332$ A1D \\
\hline
\end{tabular}

The structure of ceramic specimens with WMM coloring additive was studied successively on a macro and micro level with different degree of increase of their internal surface area (Fig.1,2).

Macrostructure of specimens was investigated using binocular magnifier on ground surface of vertical saw cut (Fig.1,a). One could note distinctive matrix structure of ceramic fragment with a marked boundary between phases of different color. Matrix structure was formed at the stage of raw material by means of granulation of fine-grained clay loam and by coating of granules with WMM additive with further compaction. While burning the formed matrix structure of raw material was transformed into ceramic matrix composite; its macrostructure consisted of ceramic cores of brick-red color coated with shell from sintering products of brown-colored manganese-containing additive.

Observations of polished section in reflected light (Fig.1,b) showed even-grained microstructure with increments of relic minerals up to $0.2 \mathrm{~mm}$ in size. The boundaries of separation between the core and coloring matrix were clear, deep interpenetration between the dispersion phase and dispersion medium of ceramic composite was not observed.
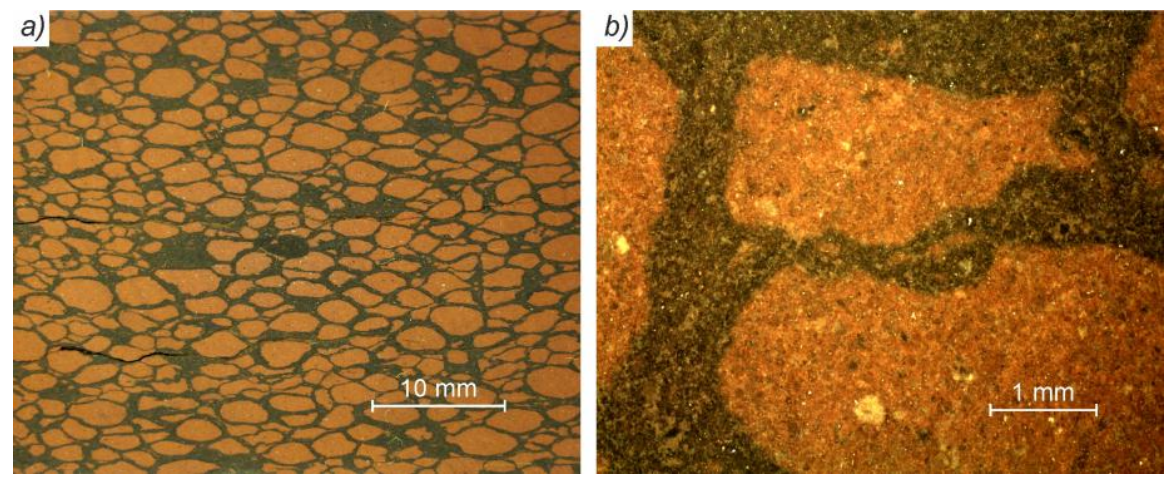

Fig. 1. Macrostructure of ceramic specimen based on Berdsk clay loam with coloring additive 10 wt.\% WMM. Conditions: polished section, reflected light, binocular magnifier $(a)$, optical microscope, nicol II (b).

Further detailed study of microstructure using electron microscope (Fig. 2) showed peculiarities of matrix and core composition. Microtexture inside the sintered granules was even, partly amorphized, with small closed pores of a round shape up to $20 \mu \mathrm{m}$ in size. By $\times 1800$ zooming one could observe hardened melt areas. The texture of matrix was presented by large-size aggregated stratum of irregular shape mostly $20-50 \mu \mathrm{m}$ in size. Porosity of boundary coloring layer was more distinctive; pores were elongated, up to 100 $\mu \mathrm{m}$ long. 

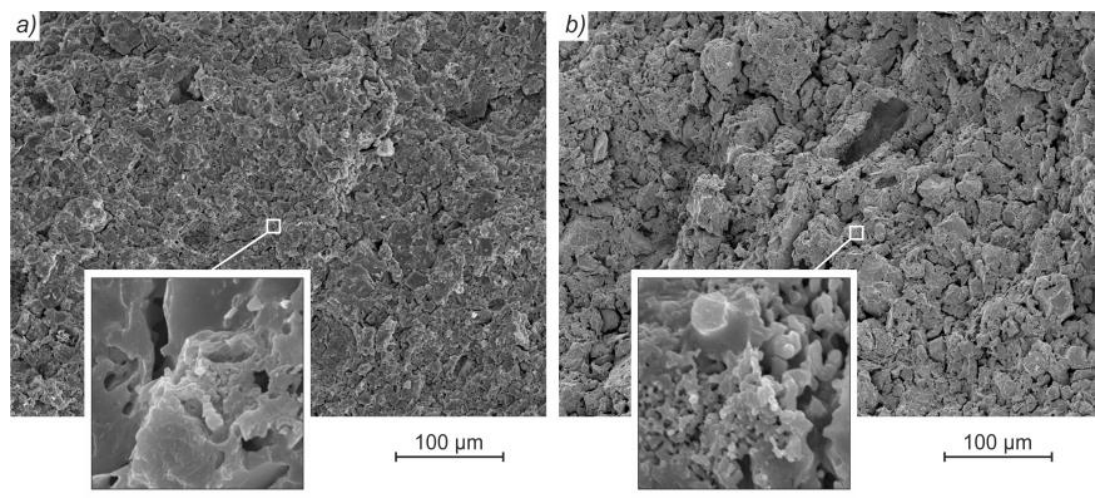

Fig. 2. SEM-micrographs of the structure of ceramic core $(a)$ and coloring boundary layer $(b)$ of ceramic matrix composite made from clay loam and WMM additive.

Investigation of phase state of ceramic specimens with WMM additive is presented in Figure 3.

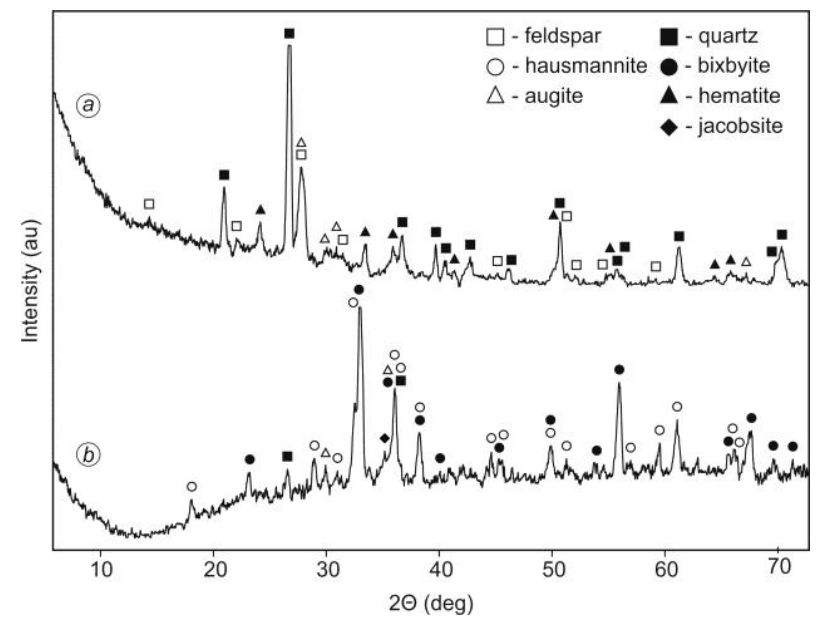

Fig. 3. X-ray diffractogram of the core $(a)$ and coloring boundary layer $(b)$ of ceramic matrix composite made from clay loam and WMM additive.

X-ray powder pattern showed that the basic mineral components of the core were quartz (4.255; 3.343; $2.457 \AA$ etc.), feldspar $(4.03 ; 3.247 ; 1.79 \AA$ etc. $)$, hematite $(3.69 ; 2.69 ; 2.52$; $1.697 \AA)$ and augite $(2.989 ; 2.917 ; 2.125 \AA)$. The boundary layer was presented by bixbyite (3.84; $2.72 ; 1.664 \AA$ etc.), hausmannite $(4.92 ; 3.08 ; 2.76 \AA$ etc. $)$, jacobsite $(2.563 ; 1.503 \AA)$, quartz and augite.

\subsection{Experimental production testing of decorative ceramic brick}

Resulting from laboratory studies held at "Berdsk Brick Factory", LLC (Berdsk city, Novosibirsk Region) (factory uses semidry compaction) pilot batch of ceramic brick was manufactured (using bulk coloring with WMM additive). The appearance of reference brick (without additive) and colored one is given in Figure 4. 
a)



b)

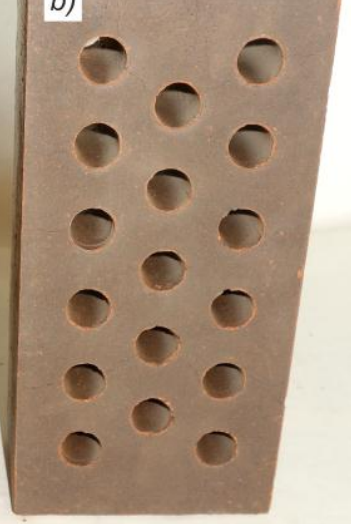

Fig. 4. Ceramic brick from red-burning Berdsk clay loam without additive (a) and with additive 10 wt.\% WMM (b).

Berdsk clay loam was used in experimental production testing. It underwent factory preparation in accordance with drying-grinding technique. WMM was subject to two-stage milling in jaw breaker and rod mill up to fraction of $-300 \mu \mathrm{m}$.

Molding material was prepared according to the developed methodology. Granules from Berdsk clay loam were aggregated up to 1-3 $\mathrm{mm}$ and powdered with fine-grained WMM additive incorporated in the amount of $10 \mathrm{wt} . \%$. Molding-moisture content of powdered granulate was $11.6-12.4 \%$.

Brick compacting was conducted using press-type machine SM-1085B. Raw products had clear boundaries and even surface without cavities and delamination cracks. Drying and burning of brick for 42 hours was held in the tunnel furnace at the temperature of $1000{ }^{\circ} \mathrm{C}$, as specified in manufacturing instructions of the factory.

The brick with 10 wt.\% WMM additive had brown color after burning (Fig.4,b) compared to the red color of the reference specimen (Fig.4,a).

Results of physical chemical tests of ceramic brick conducted in the factory laboratory are shown in Table 5.

Table 5. Physical and mechanical properties of ceramic brick of pilot batch.

\begin{tabular}{|c|c|c|c|c|c|}
\hline \multirow[b]{2}{*}{ Brick type } & \multicolumn{2}{|c|}{ Ultimate strength } & \multirow{2}{*}{$\begin{array}{l}\text { Average } \\
\text { density, } \\
\mathrm{kg} / \mathrm{m}^{3}\end{array}$} & \multirow{2}{*}{$\begin{array}{c}\text { Water } \\
\text { adsorption, } \\
\%\end{array}$} & \multirow{2}{*}{$\begin{array}{c}\text { Frost } \\
\text { resistance, } \\
\text { cycles }\end{array}$} \\
\hline & $\begin{array}{c}\text { Compressive, } \\
\mathrm{MPa}\end{array}$ & $\begin{array}{l}\text { Bending, } \\
\text { MPa }\end{array}$ & & & \\
\hline Refs & 12.1 & 2.2 & 1770 & 13.6 & 35 \\
\hline Colored & 15.3 & 2.4 & 1908 & 11.7 & 50 \\
\hline
\end{tabular}

\section{Results}

The coloring effect of additive from powdered $(-300 \mu \mathrm{m})$ wastes of manganese mining into red-burning clay raw during manufacture of ceramic brick of dry compaction was established.

The technique of obtaining decorative ceramic materials with matrix structure developed by the authors [19] provides bulk coloring of brick into brown color (RGB: 56; 
42 ; 29) when $8-10$ wt.\% of WMM is incorporated into batch composition. Along with that the strength of such products is increased by $15-20 \%$ due to concentration of coloring component along the granules surface. Thus, it eliminates the negative effect on argillaceous raw material, which is generally observed in bulk coloring technique of wall ceramics using pigments.

Formation of ceramic matrix composite was defined, its macrostructure consisted of cores covered with shell from sintering products of manganese-containing additive of a brown color. After burning cores made from clay had even-grained structure with formation of glass phase and specific hematite coloring.

Investigations of phase composition showed that the core consisted of the following basic minerals: quarts, feldspar, hematite, and augite. The boundary layer was represented by quartz and augite, as well as minerals specific for manganese compounds: bixbyite, hausmannite, and jacobsite.

\section{Conclusion}

The developed method of raw materials preparation which implies fine grinding of raw material, its granulation and powdering of the granules surface with coloring agents, is considered promising among decorative coarse ceramics techniques. The technique of obtaining decorative ceramic products with matrix structure provides effective ceramics coloring by addition of $10 \%$ manganese-containing wastes. Concentration of the coloring pigment on the surface of clay granules does not reduce physical and mechanical properties of ceramic specimens. Further development of the mentioned technique will enable to solve the problem of disturbing processes of argillaceous materials sintering while burning.

Novel technique of bulk coloring will provide effective (high coloring effect) use of industrial wastes; it will reduce expenses for decorative brick manufacturing and improve ecological situation in industrial areas.

Further research in this field is aimed at broadening the range of coloring modifiers based on industrial wastes as well as development of process-dependent parameters and modes to obtain decorative ceramic materials.

The research was performed in the framework of State Assignment of the Ministry of Education and Science of the Russian Federation, project code No. 7.7285.2017/8.9 "Basic research on ceramic matrix composite building materials based on technogenic and natural raw materials".

\section{References}

1. M. Llusar, T. Bermejo, J.E. Primo, C. Gargori, V. Esteve, G. Monrós, Ceramics International, 43(12), 9133-9144 (2017)

2. E. Adorni, Journal of the European Ceramic Society, 33(13-14), 2801-2809 (2013)

3. A.M. Salakhov, V.P. Morozov, F.G. Vagizov, A.A. Eskin, A.R. Valimukhametova, A.L. Zinnatullin, Stroitel'nye Materialy [Construction Materials], 3, 90-95 (2017) (in Russian)

4. C. Rathossi, Y. Pontikes, Journal of the European Ceramic Society, 30(9), 1841-1851 (2010)

5. K.A. Ariskina, A.M. Salakhov, F.G. Vagizov, R.T. Akhmetova, Vestnik Tekhnologicheskogo Universiteta [Herald of Kazan Technological University], 19(24), 25-28 (2016) (in Russian)

6. V.I. Reznik, Stroitel'nye Materialy [Construction Materials], 4, $54-56$ (2011) (in Russian) 
7. G.P. Vasyanov, B.F. Gorbachev, E.V. Krasnikova, R.K. Sadykov, R.R. Kabirov, Georesursy [Georesources], 4, 44-49 (2015) (in Russian)

8. A.Yu. Stolboushkin, D.V. Akst, O.A. Fomina, Dolgovechnost stroitelnykh materialov, izdelii $i$ konstruktsii [Durability of building materials, products and structures], 154160 (Publishing House of Mordovia State University, Saransk, 2016) (in Russian)

9. I.V. Petrov, D.Y. Savon, Ecologiya. Prirodopolzovanie. Ekonomika [Ecology. Environmental Management. Economics], 43-56 (Publishing House of Moscow State University for Humanities, Moscow, 2013) (in Russian)

10. L.P. Schukina, E.V. Lyubova, I.V. Bilan, M.F. Kartavenko, Stroitel'nye Materialy [Construction Materials], 8, 28-30 (2010) (in Russian)

11. A. De Bonis, G. Cultrone, C. Grifa, A. Langella, A.P. Leone, M. Mercurio, V. Morra, Ceramics International, 43(11), 8065-8074 (2017)

12. M.B. Sedelnikova, V.M. Pogrebenkov, Keramicheskie pigmenty na osnove prirodnogo $i$ tekhnogennogo mineralnogo syr'ya [Ceramic pigments based on natural and industrial mineral raw materials] (National Research Tomsk Polytechnic University, Tomsk, 2014) (in Russian)

13. S. Yeşilay, M. Çakı, H. Ergun, Ceramics International, 43(12), 8912-8921 (2017)

14. V. Valanciene, R. Siauciunas, Z. Valancius, Applied Clay Science, 99, 110-118 (2014)

15. S.R. Prim, A. Garcia, R. Galindo, S. Cerro, M. Llusar, M.V. Folgueras, G. Monros, Ceramics International, 39 (6), 6981-6989 (2013)

16. L. Maritan, L. Nodari, C. Mazzoli, A. Milano, U. Russo, Applied Clay Science, 31(12), 1-15 (2006)

17. A.Yu. Stolboushkin, Stroitel'nye Materialy [Construction Materials], 8, 24-32 (2013) (in Russian)

18. C. Gargori, S. Cerro, N. Fas, M. Llusar, G. Monros, Ceramics International, 43(7), 5490-5497 (2017)

19. A.Yu. Stolboushkin, O.A. Fomina, D.V. Akst, A.I. Ivanov, M.S. Druzhinin, Stroitel'nye Materialy [Construction Materials], 12, 38-44 (2016) (in Russian)

20. D. Pascale, A Review of $R G B$ Color Spaces ...from xyY to $R^{\prime} G$ ' $B$ (The BabelColor Company, Montreal, 2003)

21. D.S. McFarland, CSS: The Missing Manual (O’Reilly Media, California, 2015) 